\title{
Growth and Inequality in Indonesia: Does Kuznets Curve Hold?
}

\author{
G. A. Diah Utari, Retni Cristina \\ Central Bank of Indonesia, Jakarta, Indonesia
}

\begin{abstract}
Sustainable economic growth has put Indonesia as a middle-income country (MIC) and currently, the level of per capita income has already exceeded US $\$ 3,000$. The increase in income per capita is followed by the increasing number of middle-class population and the reduction in poverty. However, it has not been accompanied by declining inequality that reflects the quality of economic growth. According to Kuznets theory, an increase in inequality is a common problem in the process of economic growth. Inequality will further decline after the country has reached a certain threshold level of income. This study aims to analyze the trend and nature of income inequality in Indonesia and to test whether the Kuznets Curve holds. This paper used dynamic panel method with 26 provincial panel data from 2000 to 2011. The empirical result proves the existence of inverted U-shaped Kuznets Curve in Indonesia and it may have the turning points when the real GDP per capita in each province reached Rp. 179.41 million/year or around US\$17.000. For the determinant of inequality in Indonesia, this study found that the percentage of urban population, inflation, and share of agricultural sector contributed to the increase of inequality, while high-level education and share of industrial sector are associated with the lower level of inequality.
\end{abstract}

Keywords: growth, middle class, poverty, inequality, Kuznets Curve, dynamic panel

\section{Introduction}

The Indonesian economy has regained the status of lower middle-income countries (MICs) since 2003 and currently, the level of per capita income has already exceeded US $\$ 3,000$. The increase in per capita income is followed by the increasing number of people who are in the middle class and the declining number of people who are in poor or near poor category (see Figure 1). With its robust recent growth performance, which has been growing at $5.7 \%$ on average over the last decade and endurance throughout the global financial crises, Indonesia is gaining prominence as an emerging market economy with global influence. It is also considered as one of the largest MICs in the world.

An increasing number of middle-class categories have positive sides, but at the same time, there are also challenges. On the positive side, it will create potential demand for goods and services and thus will boost investment opportunity. The increasing number of middle-income people benefited the government, because it raised potential tax payers and can gradually reduce the amount of government's subsidy. However, we also have to be aware of the fact that this social transformation can lead to a middle-income trap.

G. A. Diah Utari, senior researcher, Centre for Central Banking Research and Educations, Central Bank of Indonesia. Email: utari@bi.go.id.

Retni Cristina, researcher, Centre for Central Banking Research and Educations, Central Bank of Indonesia. 


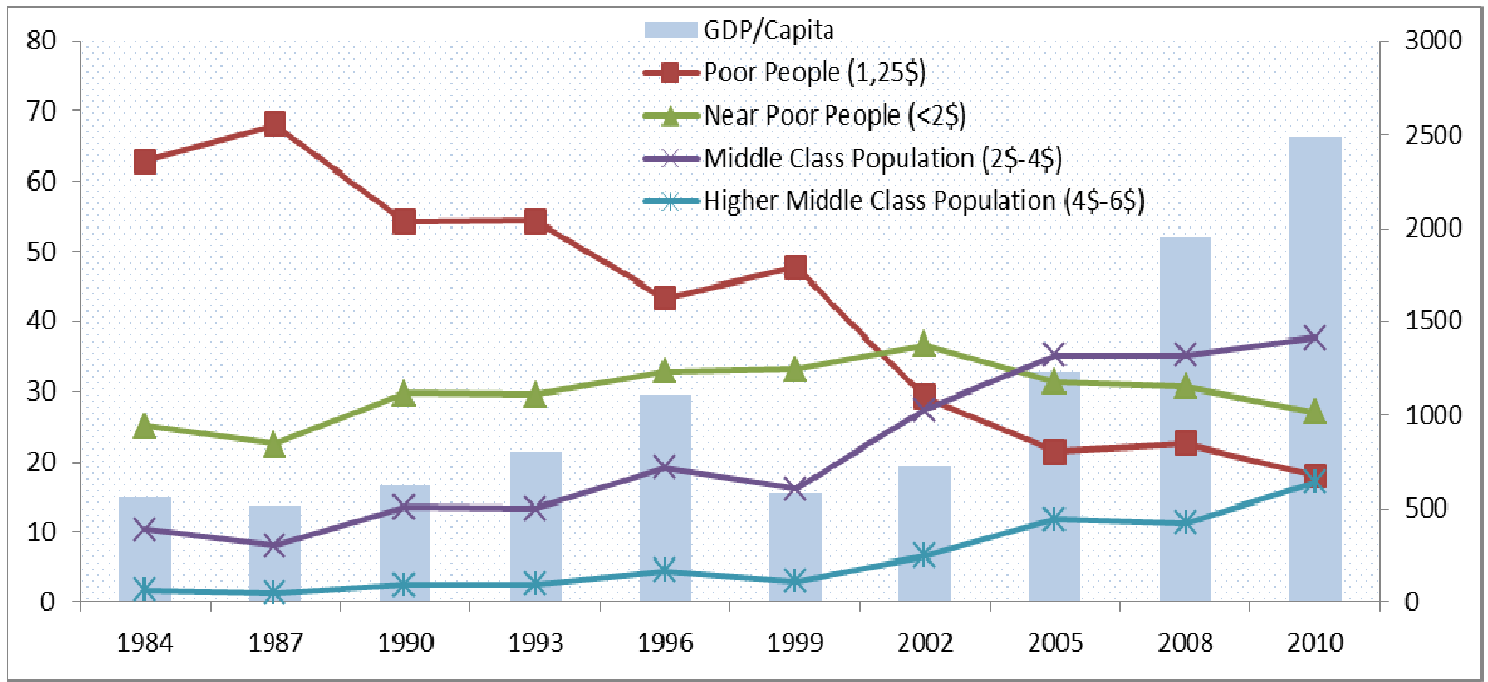

Figure 1. GDP/capita and percentage of middle-class people. Source: Povcal Net and World Bank.

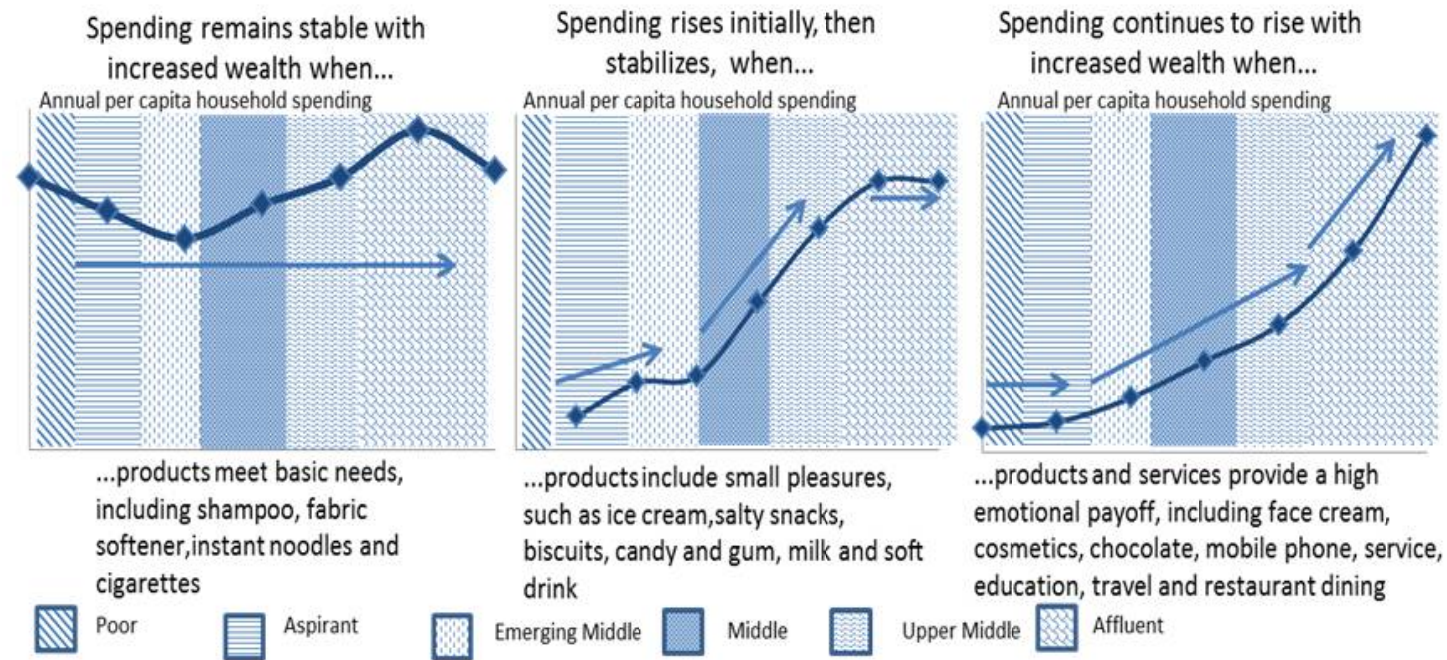

Figure 2. Wealth and spending. Source: Boston Consulting Group.

As income rises and living standards improve, consumers' needs also follow a natural progression from products that previously address just their basic needs to those that offer greater convenience. Survey from Boston Consulting Group (2012) shows that there is a big jump in the purchase of consumer durable products and high-tech products are the most popular one for the middle class (see Figure 2). The domestic needs for high-tech products are mostly fulfilled from abroad. This can be seen in the structure of Indonesian import reflecting the dependence on goods of high added value (see Figure 3). On the other hand, the ability of domestic industries to produce high-tech products is still limited. The structure of Indonesian export products is still dominated by energy/resource commodities (see Figure 4). Therefore, economic actors that can exist are those that are able to supply goods and services of high added value and are innovative. If domestic industries cannot satisfy the increasing need of the middle-income group, this would be a risk for the achievement of sustainable growth path in the future, which could lead Indonesia to stuck in the current level of income (middle-income trap). 


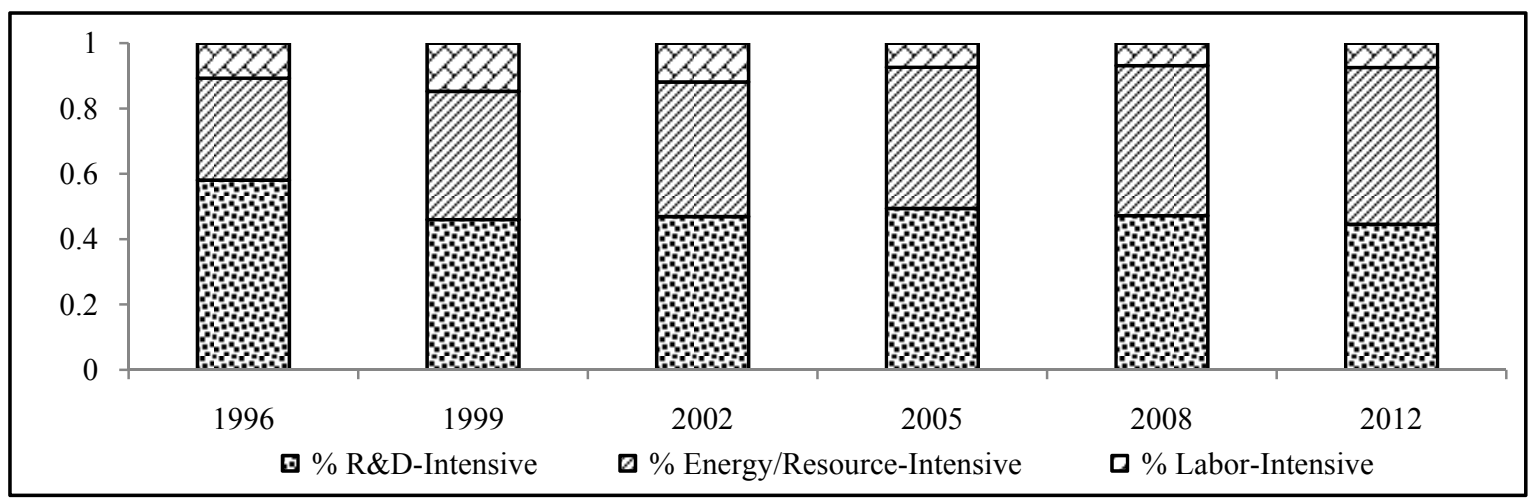

Figure 3. Indonesia's import structure. Source: United Nations Conference on Trade and Development (UNCTAD).

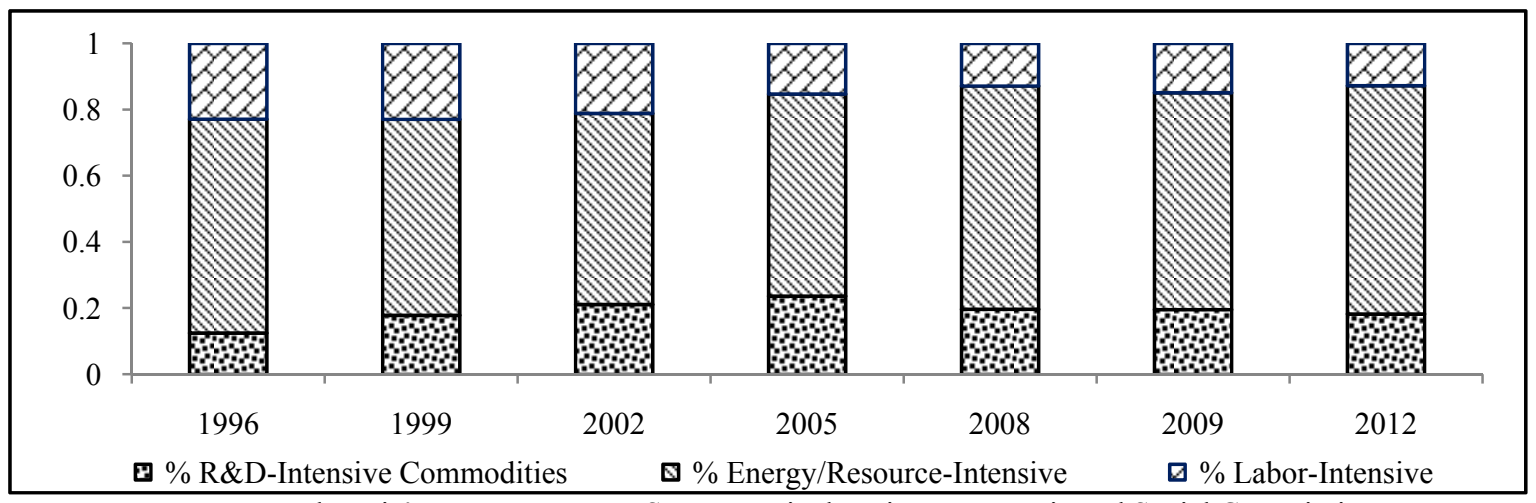

Figure 4. Indonesia's export structure. Source: United Nations Economic and Social Commission

for Asia and the Pacific (UNESCAP).

Another challenge that we also have to face is the increasing inequality which is represented by the Gini ratio $^{1}$. For almost three decades, GDP per capita has increased by five times, but Gini ratio has also increased from 0.30 in 1984 to 0.41 in 2012 (see Figure 5).

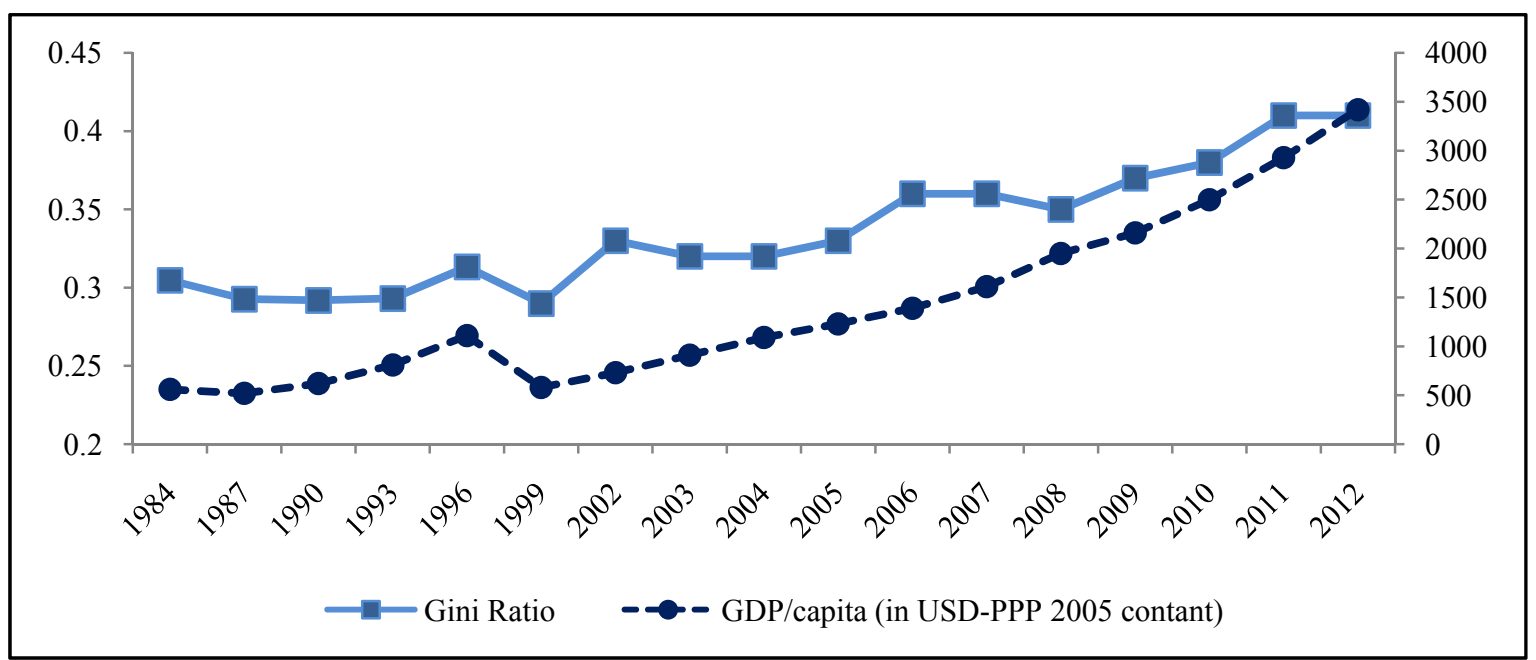

Figure 5. GDP/capita and inequality. Source: Statistics Indonesia BPS.

\footnotetext{
1 The Gini coefficient is derived from the ratio of the share of income going to the lowest quintile of the income distribution and the share going to the highest quintile. The Gini coefficient can be viewed as an average of deviations of quintile shares from 0.2 , the value that holds under full equality (Barro, 2008).
} 
Based on the abovementioned background, it is necessary to analyze how the quality of economic development in Indonesia could support the long-term goal of achieving a sustainable and equitable growth. Therefore, the aim of this paper is:

(1) To analyze the trend of income inequality in Indonesia and how it evolves as the income level rises;

(2) To test whether the Kuznets Curve holds and if it is proven to hold, then we would like to find the turning point of the income level.

\section{Growth and Inequality in Indonesia}

Indonesia had successfully maintained quite high economic growth and reduced poverty (see Figure 6) during the period from the 1980s to the mid-1990s. In line with the increase of GDP per capita (see Figure 7), the number of poor people ${ }^{2}$ decreased from 35 million in 1984 (21.6\% of total population) to 22.5 million in 1996 (11.3\% of total population). In 1996, the methodology was revised and the percentage of poverty with the new definition was estimated at $17.5 \%$. In 1998, poverty jumped significantly due to the impact of the Asian financial crises before it started to decrease in 2000. Afterwards, poverty kept going down except in 2006, which was due to rising domestic oil price that drove up the price of staple food. As a result, people who were not classified as poor but whose income was around the poverty line shifted to the poor category. Even though the average growth rate after the crises $^{3}(5.6 \%)$ is smaller than that before the crisis ${ }^{4}(6.7 \%)$, the declining rate of the number of poor people is higher. After the crises, the number of poor people was reduced over 1.45 million each year (or about $0.88 \%$ a year), while before the crises, the declining rate was 1.04 million people a year (or about $0.85 \%$ a year). This indicates an improvement in the government poverty alleviation program after the crises.

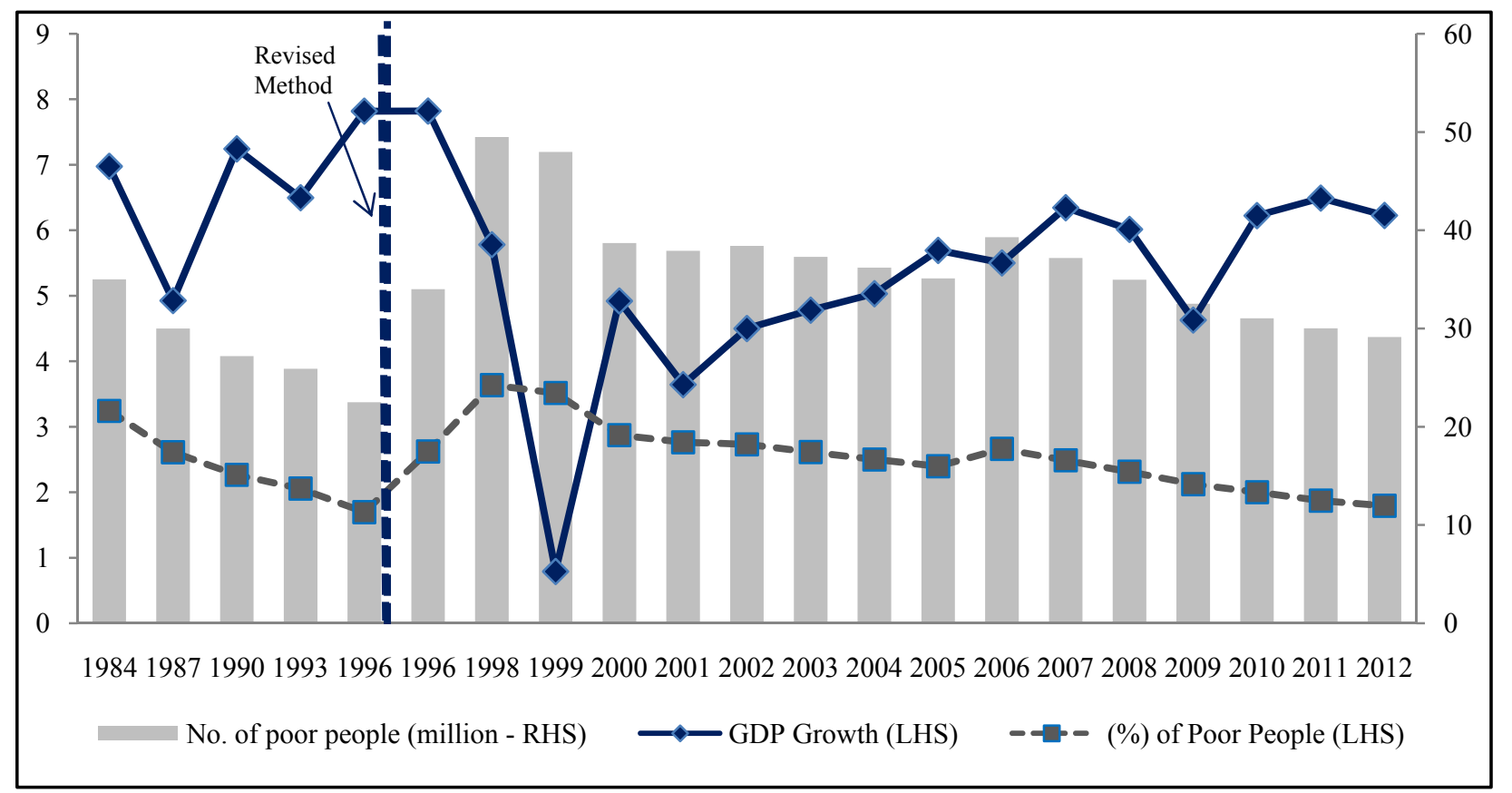

Figure 6. GDP growth and poverty. Source: BPS.

\footnotetext{
${ }^{2}$ According to BPS, people are classified as poor people if their monthly income per capita is below the poverty line.

${ }^{3}$ Period before the crisis is calculated between 1984 and 1996.

${ }^{4}$ Period after the crisis is calculated between 1999 and 2012.
} 


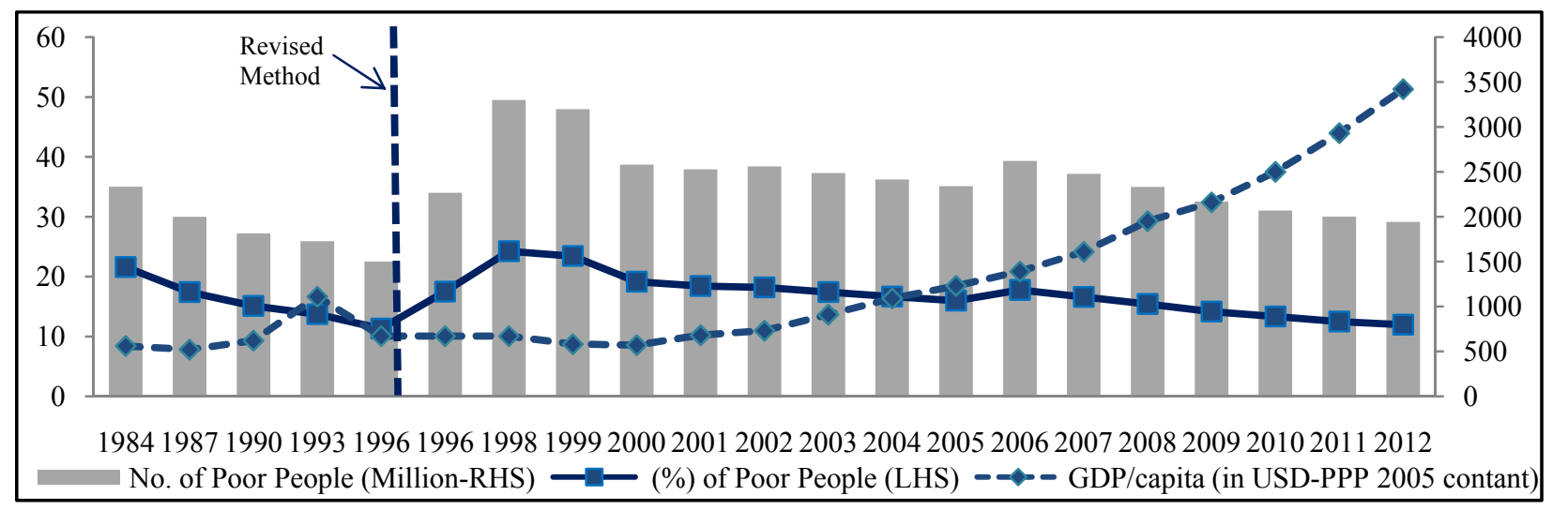

Figure 7. GDP per capita and poverty. Source: UNESCAP and BPS.

Although both the GDP per capita and the number of poor people have gradually increased and decreased respectively after the crises, the inequality as indicated by Gini ratio tends to increase (see Figure 8 ). The inequality decreases during the period of 1984-1987 in line with the decrease of GDP growth. After 1987, Gini coefficient was relatively stable and began to increase from 1993 to 1996. During this period, the economic growth was relatively high, which stood between $6 \%$ and $8 \%$ (see Figures 3-12). The Gini ratio then declined as a result of the 1997 Asian Financial Crisis (AFC). Comparing to the period before the crises, the inequality tends to increase for the last decade. There was a relative constancy of the overall Gini index before the crises. It changed very slightly, which was only 0.01 over 12 years (1984-1996). After the crises (1999-2012), the Gini index increases to 0.12 point, 10 times higher than the period before.

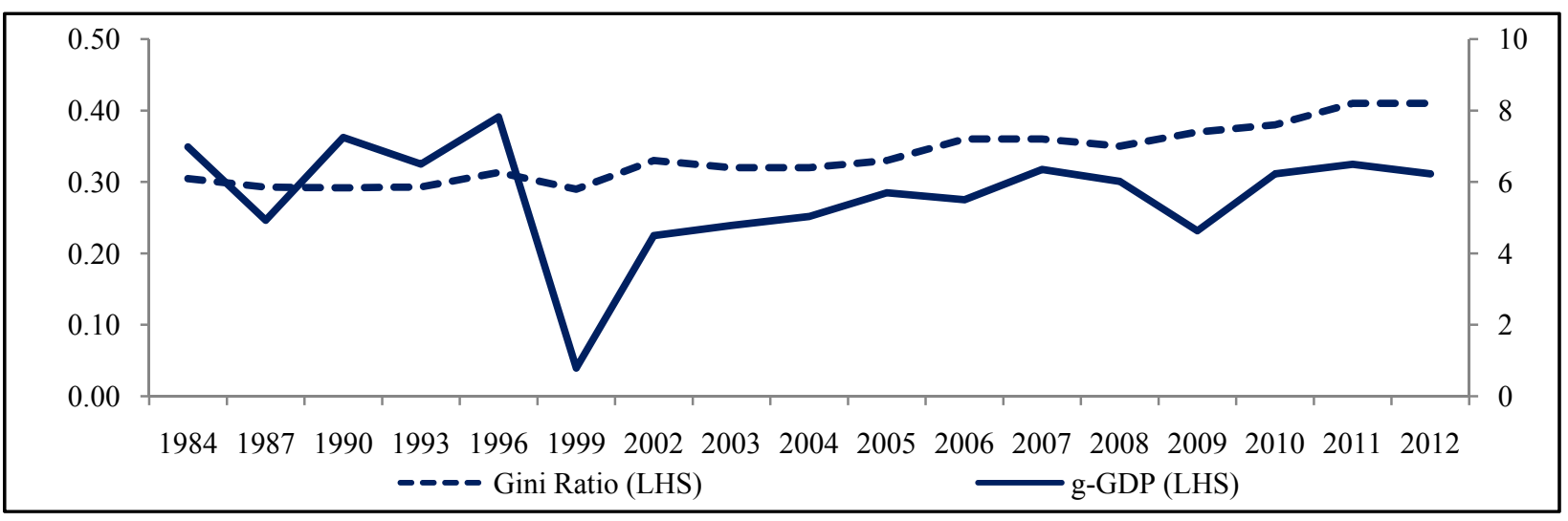

Figure 8. GDP growth and Gini ratio.

Figure 9 shows the share of national income that is proxied by expenditure of three income groups, namely, the $20 \%$ richest households, the $40 \%$ middle-income households, and the $40 \%$ poorest households. The $20 \%$ richest households enjoy, on average, $44 \%$ of income while the middle-income households and the poorest households enjoy $37 \%$ and $20 \%$ of income respectively. For the last three years, it seems that there is a significant increase in the share of income enjoyed by the $20 \%$ richest households, which is accompanied by the decline in income share of the $40 \%$ poorest households and the $40 \%$ middle-income households. By the end of 2012 , the share of income enjoyed by the richest group was $49 \%$, increased from $41 \%$ in 1999 . During the period of $1999-2012$, the $20 \%$ highest income group has gained $20 \%$ additional share, while the $40 \%$ poorest and the middle-income households have loosed income share by $22 \%$ and $9.5 \%$ respectively. 


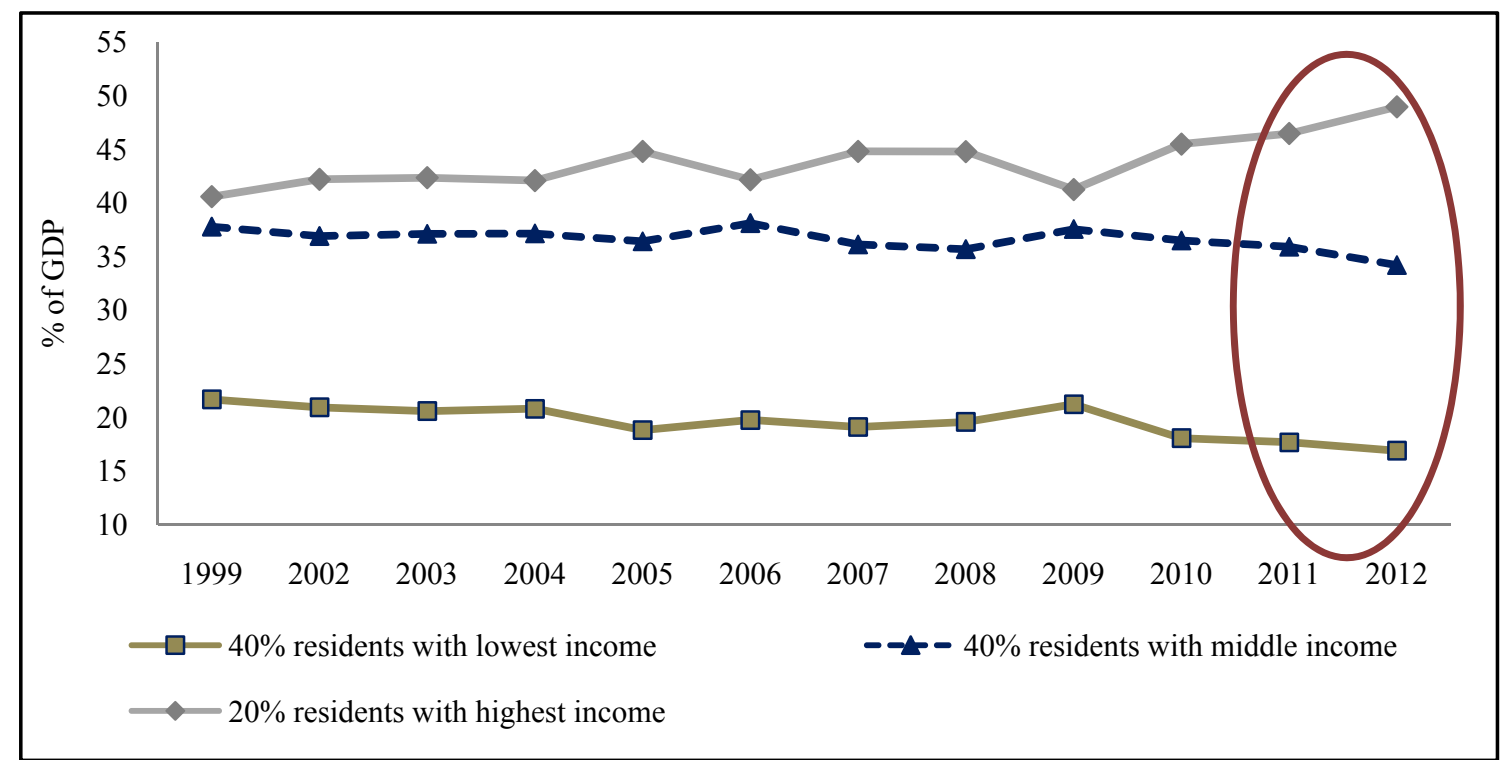

Figure 9. Share of national income. Source: BPS.

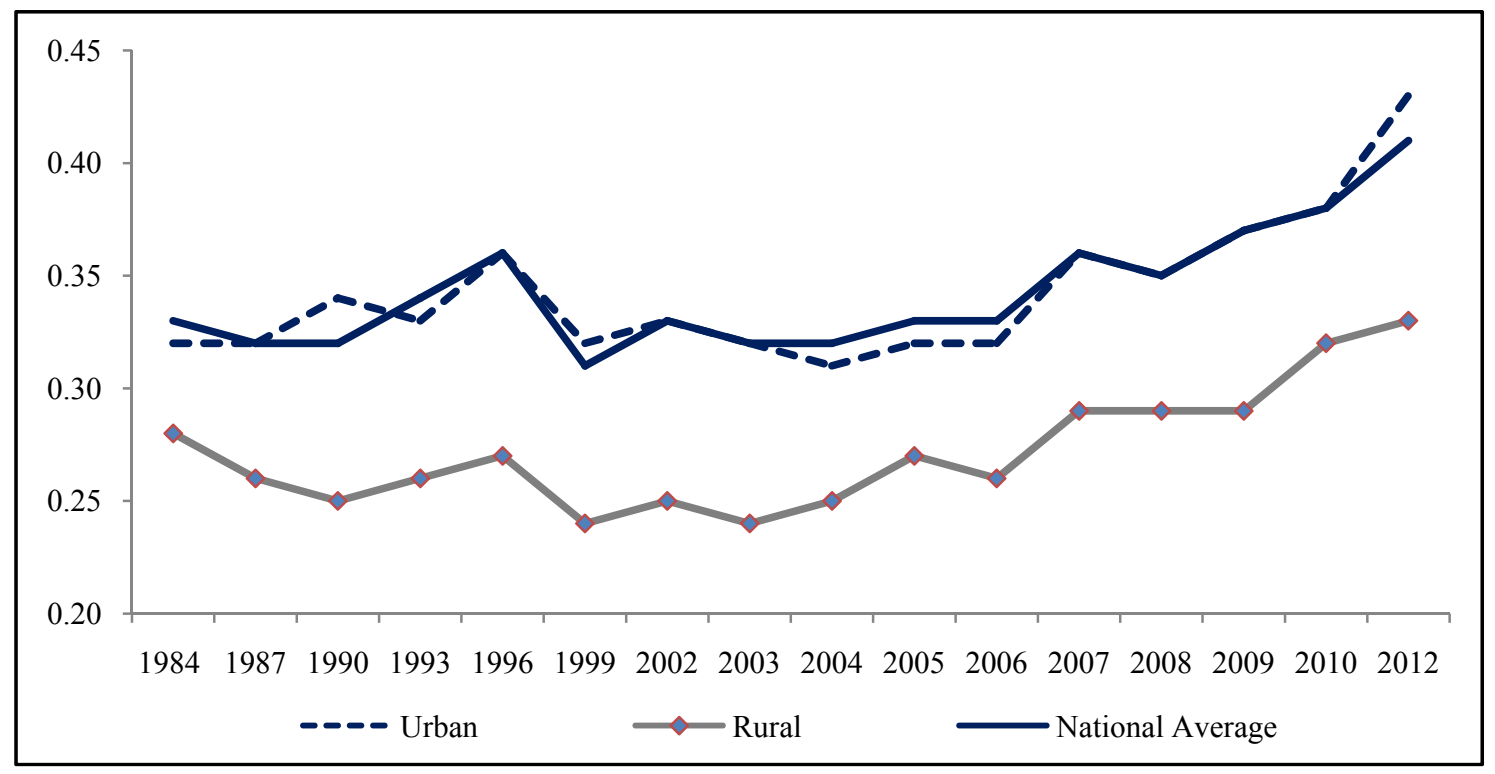

Figure 10. Gini ratio (urban-rural-national). Source: BPS.

After the AFC, the domestic economy had been exposed to the volatility of global economic conditions which contributed to the increase of inequality. In late 2005, the hike of world oil prices forced the government to raise domestic oil prices that pushed inflation higher. Inflation reduces the real income and the impact is worse to low-income people compared to the high-income one. As a result, we see the increase of inequality in 2006. Later in the period after 2008, the impact of the subprime mortgage crisis also spread to financial markets in developing countries. Subprime mortgage crisis has triggered a reversal of capital flows in developing countries so that the exchange rate and asset prices fall. In addition, the impact of the subprime mortgage crisis is also accompanied by soaring oil prices, followed by a rise in prices of many other commodities. The combination of all these events caused considerable inflationary pressures to domestic economy which contributed to the increase of inequality after 2008. 
Inequality seemed to be more apparent in urban Indonesia, reaching a level of 0.43 in September 2012, compared to rural areas with a level of 0.33 (see Figure 10). Inequality in both urban and rural areas shows an increasing trend. Inequality in urban areas was higher than in rural areas and was very close to the national average. The influence of urban Gini on the national aggregate grew over time as Indonesia's urban population increased rapidly over the last decades. As stated in Kanbur and Zhuang (2013), urbanization contributed more than $50 \%$ of the increase in inequality in Indonesia at the national level. According to World Bank Report (2010), Indonesia has grown to become one of the most urbanized countries in the region. Based on UNESCAP data, the urban population in 2012 was $44.9 \%$. Comparing with average South East Asian countries, urban population in Indonesia is relatively higher (see Figure 11). The urban population has exceeded the South East Asian average since 1995. According to the study of Lewis (2013), the level of urbanization is positively associated with economic growth. For some richer countries in Asia like Korea, Japan, and Malaysia, they do have a high level of urban population (see Figure 12).

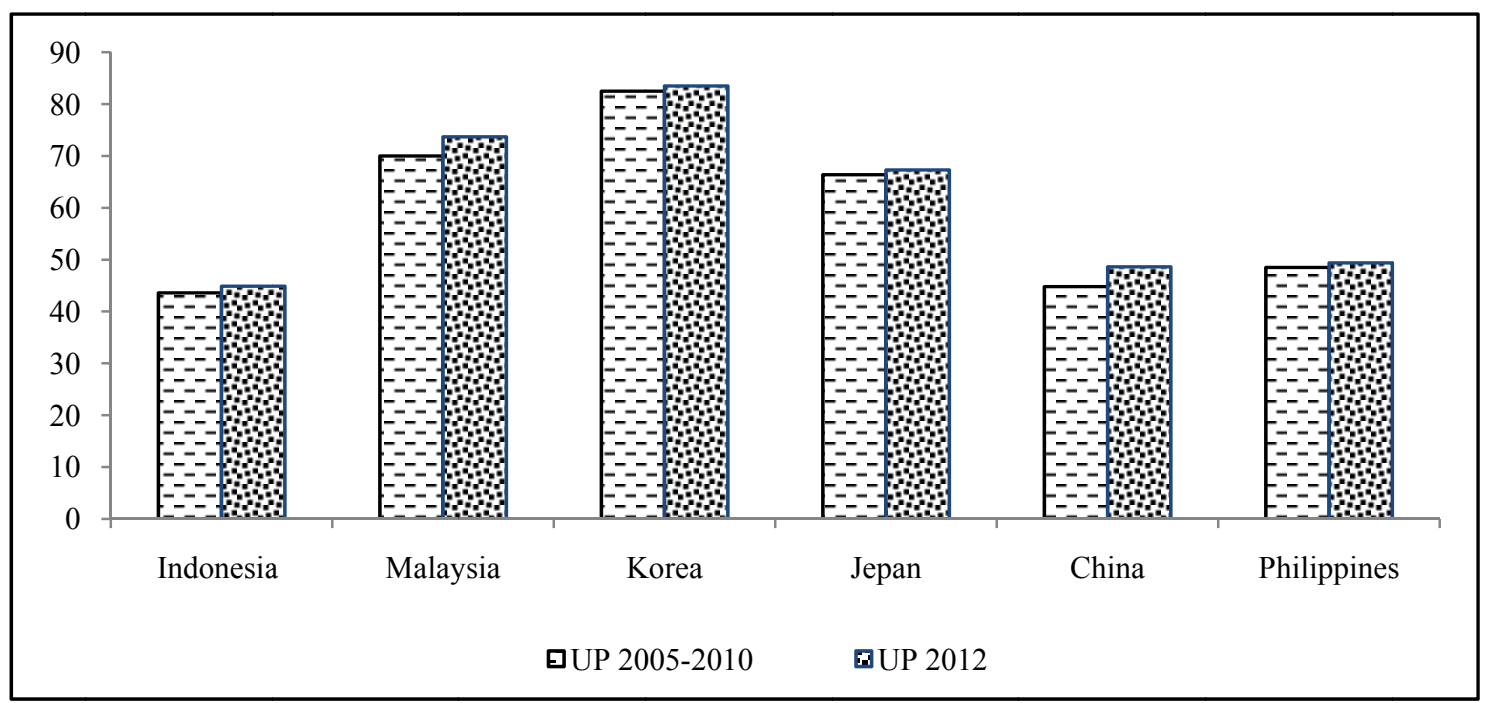

Figure 11. Indonesian urban population and South East Asia average. Source: UNESCAP.

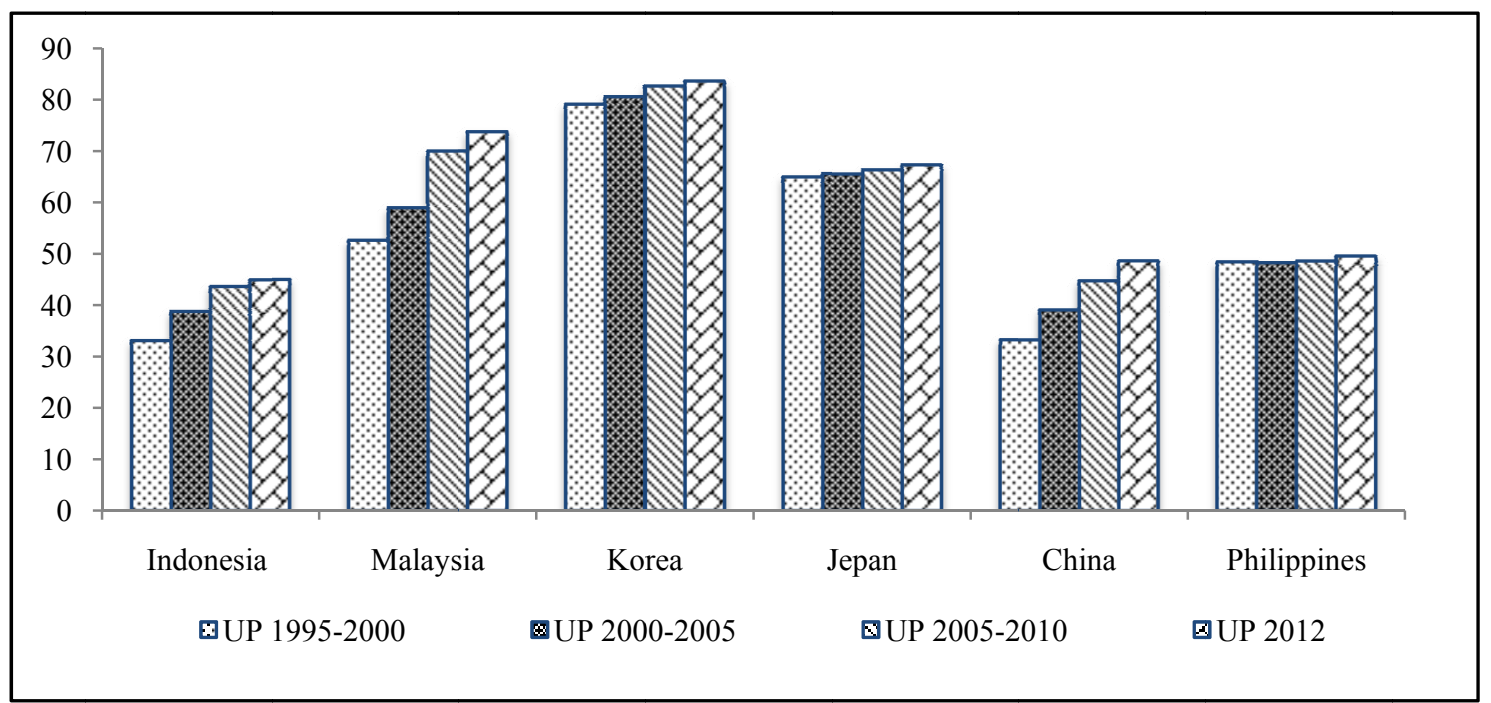

Figure 12. Urban population of some countries. Source: UNESCAP. 
The pattern of rising inequality also occurred in provinces. From Table 1, we can see that almost all provinces experienced worsening inequality in 2012 compared to 1984, almost two decades before. The provincial average of inequality increased from 0.29 in 1984 to 0.31 in 1996 and then to 0.32 in 2008 , and became 0.38 in 2012. There is a significant increase in the provincial average Gini ratio from 2008 to 2012 (17.9\%), compared to the increase from 1984 to 1996 (4.5\%) and from 1996 to 2008 (4.7\%). In 1984, the number of provinces that have inequality above national average is 13 and in 1996, it declined to 10 provinces.

Table 1

Inequality in Provinces

\begin{tabular}{|c|c|c|c|c|c|}
\hline No. & Province & 1984 & 1996 & 2008 & 2012 \\
\hline 1 & Papua & 0.37 & 0.39 & 0.40 & 0.44 \\
\hline 2 & Gorontalo & & & 0.34 & 0.44 \\
\hline 3 & DIY & 0.34 & 0.38 & 0.36 & 0.43 \\
\hline 4 & West Papua & & & 0.31 & 0.43 \\
\hline 5 & Bali & 0.29 & 0.31 & 0.30 & 0.43 \\
\hline 6 & North Sul & 0.35 & 0.34 & 0.28 & 0.43 \\
\hline 7 & DKI & 0.29 & 0.36 & 0.33 & 0.42 \\
\hline 8 & South Sul & 0.35 & 0.32 & 0.36 & 0.41 \\
\hline 9 & West Java & 0.30 & 0.36 & 0.35 & 0.41 \\
\hline 10 & Central Sul & 0.30 & 0.30 & 0.33 & 0.40 \\
\hline 11 & South East Sul & 0.32 & 0.31 & 0.33 & 0.40 \\
\hline 12 & Riau & 0.26 & 0.30 & 0.31 & 0.40 \\
\hline 13 & South Sum & 0.27 & 0.30 & 0.30 & 0.40 \\
\hline 14 & Banten & & & 0.34 & 0.39 \\
\hline 15 & South Kal & 0.26 & 0.29 & 0.33 & 0.38 \\
\hline 16 & Central Java & 0.31 & 0.29 & 0.31 & 0.38 \\
\hline 17 & West Kal & 0.25 & 0.30 & 0.31 & 0.38 \\
\hline 18 & Maluku & 0.30 & 0.27 & 0.31 & 0.38 \\
\hline 19 & Lampung & 0.29 & 0.28 & 0.35 & 0.36 \\
\hline 20 & NTT & 0.31 & 0.30 & 0.34 & 0.36 \\
\hline 21 & East Kal & 0.36 & 0.32 & 0.34 & 0.36 \\
\hline 22 & East Java & 0.31 & 0.31 & 0.33 & 0.36 \\
\hline 23 & West Sum & 0.26 & 0.28 & 0.29 & 0.36 \\
\hline 24 & Bengkulu & 0.21 & 0.27 & 0.33 & 0.35 \\
\hline 25 & NTB & 0.30 & 0.29 & 0.33 & 0.35 \\
\hline 26 & Kepri & & & 0.30 & 0.35 \\
\hline 27 & North Mal & & & 0.33 & 0.34 \\
\hline 28 & Jambi & 0.20 & 0.25 & 0.28 & 0.34 \\
\hline 29 & North Sum & 0.26 & 0.30 & 0.31 & 0.33 \\
\hline 30 & Central Kal & 0.29 & 0.27 & 0.29 & 0.33 \\
\hline 31 & Aceh & 0.26 & 0.26 & 0.27 & 0.32 \\
\hline 32 & West Sul & & & 0.31 & 0.31 \\
\hline 33 & Babel & & & 0.26 & 0.29 \\
\hline Above average & & 13 & 10 & 17 & 18 \\
\hline Below average & & 13 & 16 & 16 & 15 \\
\hline Provincial average & & 0.29 & 0.31 & 0.32 & 0.38 \\
\hline
\end{tabular}

Note. Source: BPS and the authors' calculation. 
After the crises, if we take a look at more recent periods of 2008 and 2012, in 2012, there are 18 provinces that have inequalities above national average, increased from 17 provinces in 2008. For the period of 2008-2012, Bali, West Papua, and North Sulawesi experienced the highest increase in Gini coefficient. Among 18 provinces with inequality above national average in 2012, some of them are provinces with urban population or GDP per capita above provincial average. Provinces with urban population above national average are DKI, DIY, Banten, West Java, East Kal, Bali, Riau, East Java, Central Java, North Sumatra, North Sulawesi, and NTB (see Figure 13). Provinces with GDP per capita above provincial average are DKI, Riau, West Papua, Papua, and West Sulawesi (see Figure 14). The high inequality in urban areas occurs because these places can attract large numbers of less-skilled people who think that there are more economic opportunities in urban areas than in rural areas. Meanwhile, there are also high inequalities in provinces with high GDP per capita. Except for DKI, those provinces with high GDP per capita have abundance of natural resources. Using national average for GDP per capita and inequality (see Figure 15), we can see that there are four provinces that have both GDP per capita and inequality above average. Meanwhile, there are only three provinces (Babel, Riau, and West Sulawesi) with GDP per capita above average and inequality below average.

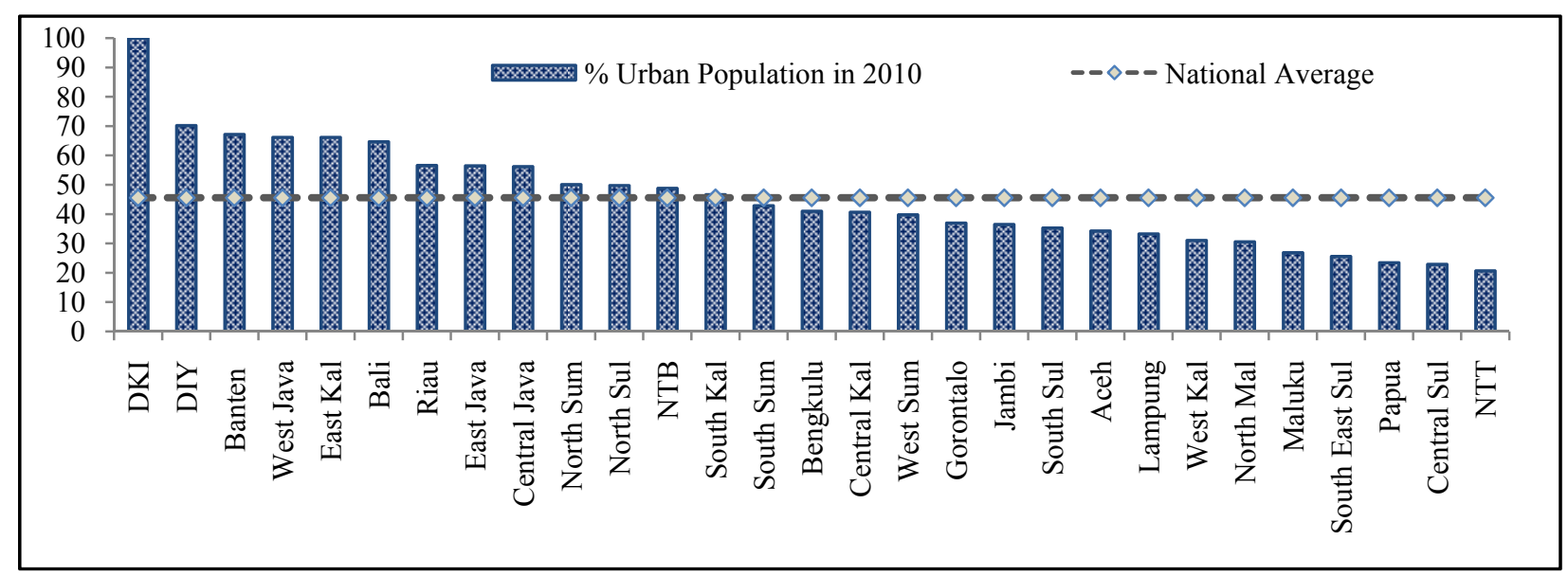

Figure 13. Urban population provinces. Source: http://www.datastatistik-indonesia.com.

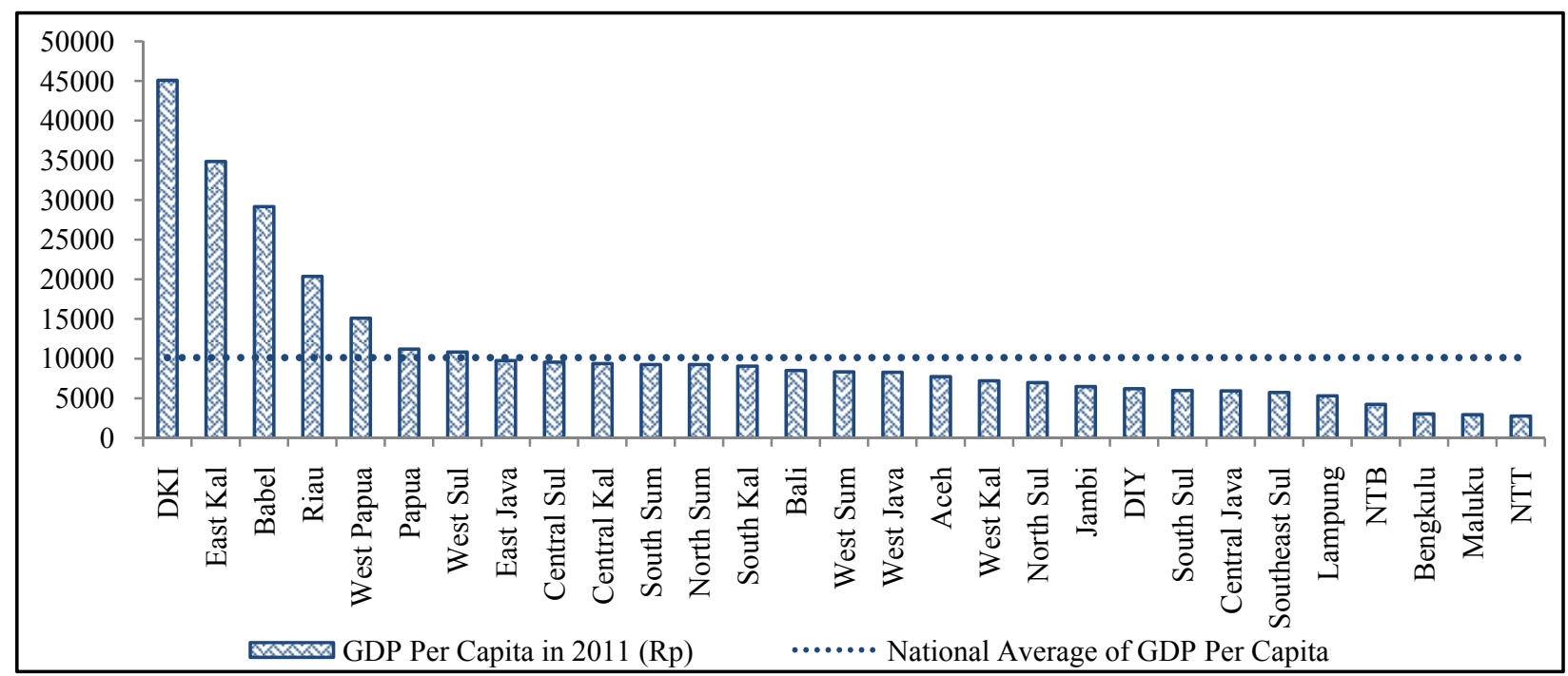

Figure 14. GDP/capita by provinces. Source: BPS. 


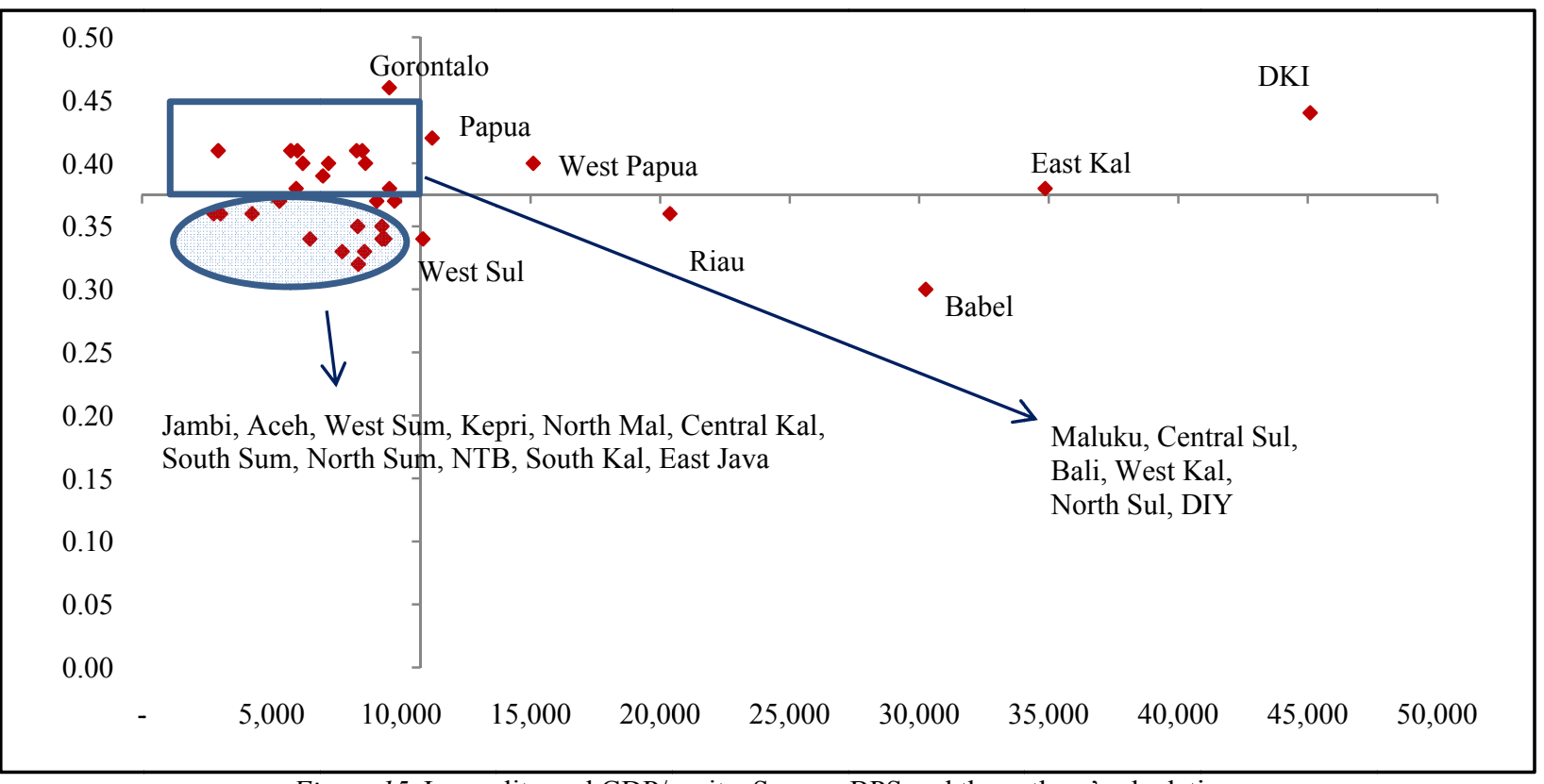

Figure 15. Inequality and GDP/capita. Source: BPS and the authors' calculation.

We also adopt the approach used in the paper by OECD (Miranti, Vidyattama, Hansnata, Cassells, \& Duncan, 2013 $)^{5}$ to see the persistence in inequality between two points in time in 2001 and 2012. From Figure 16, we see that Papua and DIY are provinces with a degree of inequality persisted at the same high level in 2001 and 2012. Lampung, NTT, South Sulawesi, and South East Sulawesi move from medium to high persistence. Jambi and Central Kalimantan have the less increment of Gini during the period of 2001-2012, compared to other provinces.

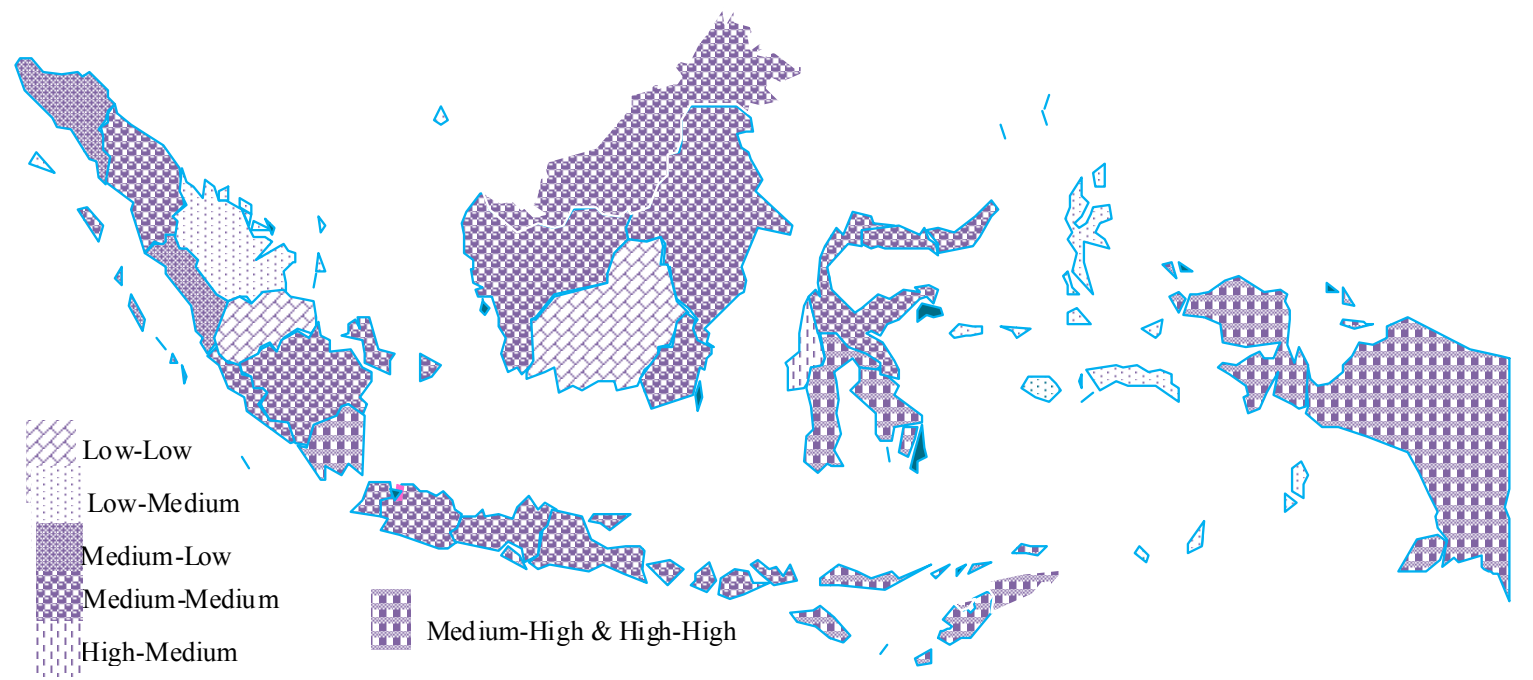

Figure 16. Persistence of inequality (2001 and 2012).

\footnotetext{
${ }^{5}$ This method was mentioned in OECD working paper by Miranti et al. (2013). The classification is divided using standard deviation from the average. Persistence of poverty or inequality is classified as follows: (1) Low = poverty or inequality rate $<$ (average - standard deviation); (2) Medium $=$ (average - standard deviation $) \leq$ poverty or inequality rate $\leq$ (average + standard deviation); and (3) High = poverty or inequality rate $\geq$ (average + standard deviation $)$.
} 
Figure 17 shows the annual change in inequality between 2001 and 2012. The three provinces that experienced the most rapid decline in inequality are Gorontalo, North Sulawesi, and Maluku. For Papua Barat, Papua, and DIY, where inequality is persistently high, the annual change in inequality is small. The same pattern also occurs for provinces that have low inequality like Bangka Belitung.

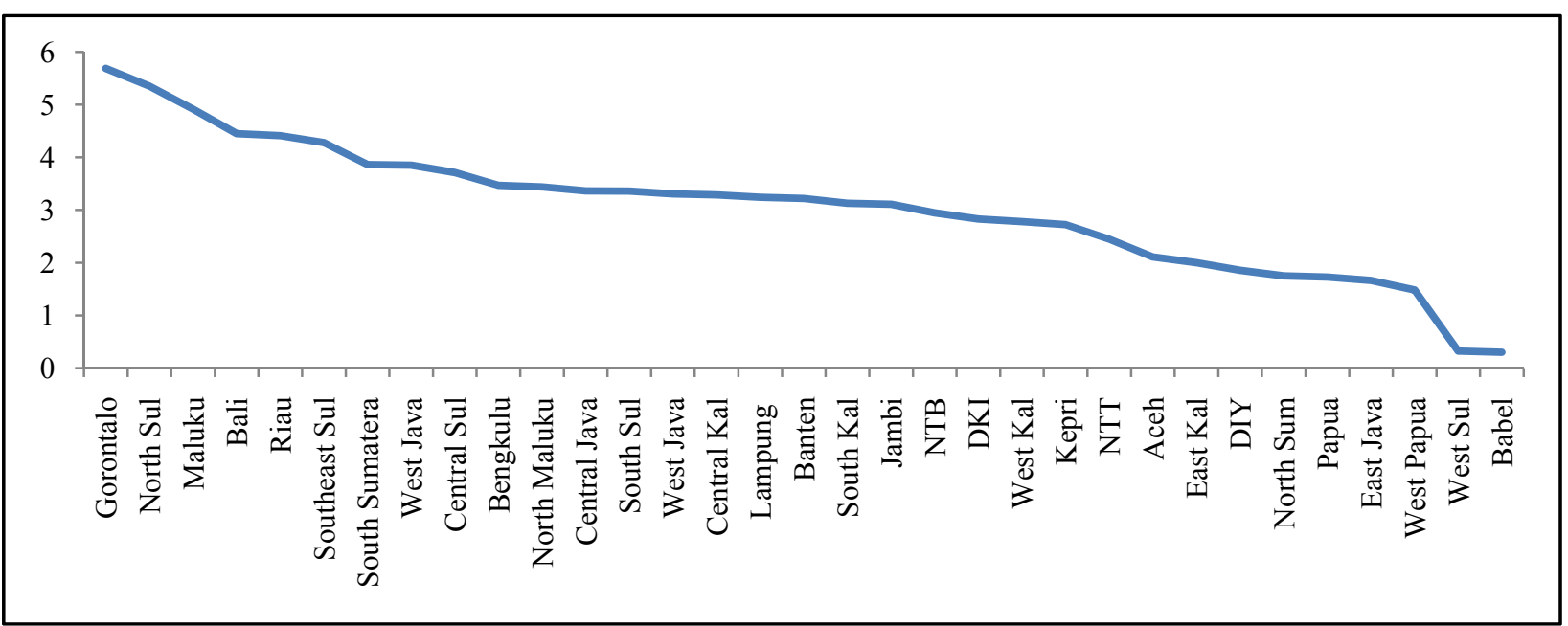

Figure 17. Annualized change in inequality (2001-2012).

Among regions in Indonesia, Java and Sulawesi have the highest economic inequality from time to time followed by Maluku-Papua, Bali-NTB, Kalimantan, and Sumatra (see Figure 18).

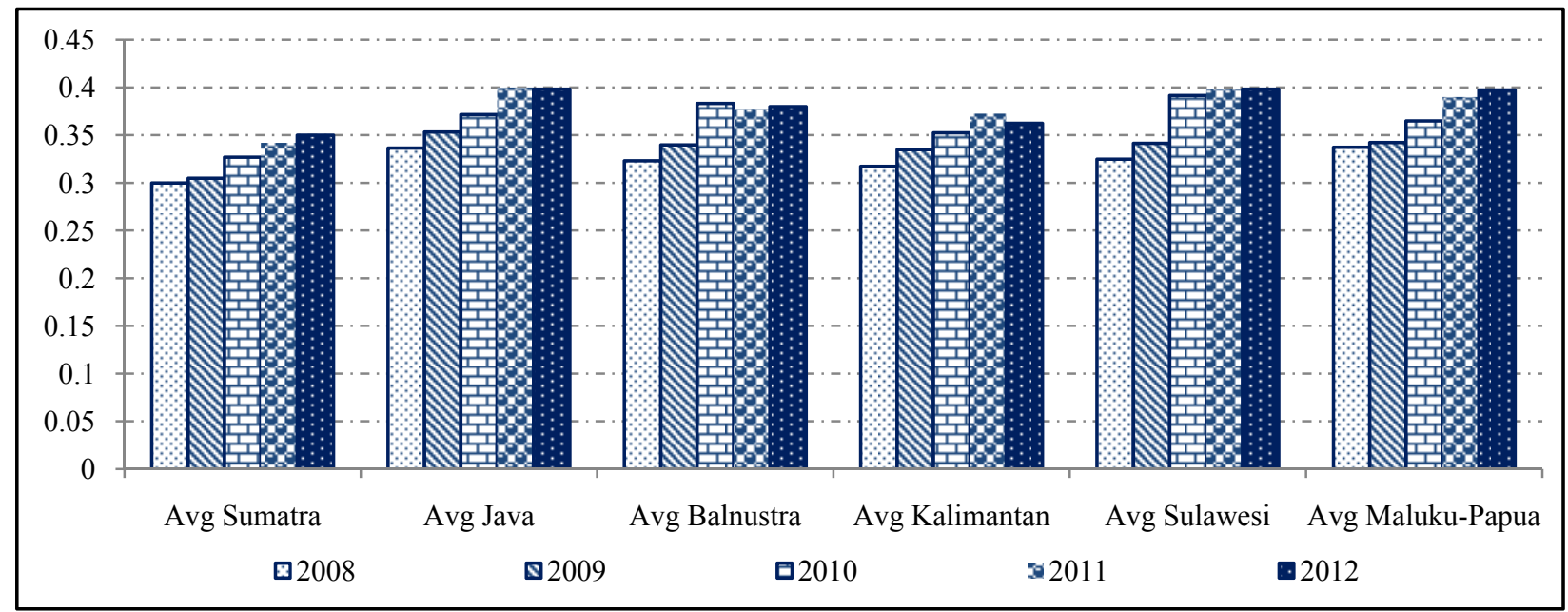

Figure 18. Inequality across regions.

From the fact above, we can get a rough conclusion for the trend of growth and poverty and inequality in Indonesia: (1) Poverty has been decreased while inequalities have been increased by both national aggregate and provincial data; (2) The increase in GDP per capita has succeeded in reducing the number of poor people, but inequality is keep rising. The increase in inequality for the last five years is higher compared to that in the period of two decades before; and (3) Higher inequalities mostly occurred in urbanized provinces or in provinces with high GDP per capita. Therefore, the next question we would like to explore is whether the ongoing increase of inequality follows the Kuznets hypothesis or not. 


\section{Methodology and Data}

There are two questions that we would like to explore in this paper: (1) "Whether the Kuznets Curve holds true for Indonesia?"; and (2) "Is there an increase in the current inequality reflecting the process of which the Kuznets theory mentioned?". In addition, we aim to analyze the determinant of inequality.

When testing the Kuznets Curve, the functional specification to be estimated is Equation (1). This method was also applied by Frazer (2006) to test economical Kuznets Curve and by Stern (2004) and Lessmann (2011) to test spatial inequality and development:

$$
\operatorname{Gini}_{i, t}=C+\alpha \ln (\text { Ycap })_{i, t}+\beta \ln (\text { Ycap })_{i, t}^{2}+\varepsilon_{i, t}
$$

where $\operatorname{Gini}_{i, t}=$ income inequality (Gini ratio) in province $i$ at year $t$, Ycap $=$ GDP per capita of province $i$ at year $t$, and $\ln$ is natural logarithm.

This paper uses the dynamic panel method to test the existence of inverted U shape of the Kuznets Curve. This approach was also used in the studies of Li and Zou (1998), Calderon and Chong (2001), Ranjan (2001), and Nikoloski (2009), and the specification of the model is:

$$
\text { Gini }_{i, t}=C+\gamma \text { Gini }_{i \cdot(t-1)}+\alpha \ln (\text { Ycap })_{i, t}+\beta \ln (\text { Ycap })_{i, t}^{2}+\varepsilon_{i, t}
$$

where $\operatorname{Gini}_{i, t}=$ income inequality (Gini ratio) in province $i$ at year $t, Y c a p=$ GDP per capita of province $i$ at year $t$, and $\ln$ is natural logarithm.

Given this model, Arcand, Berkes, and Panizza (2012) and Lind and Mehlum (2010) showed that in order to check the presence of an inverted-U relationship, it is necessary to formulate the following joint null hypothesis:

$$
\mathrm{H}_{0}:\left(\alpha+2 \beta(\text { Ycap })_{\min } \leq 0\right) \cup\left(\alpha+2 \beta(\text { Ycap })_{\max } \geq 0\right)
$$

Against the alternative:

$$
\mathrm{H}_{1}:\left(\alpha+2 \beta\left(\text { Ycap }_{\min }>0\right) \cap\left(\alpha+2 \beta(\text { Ycap })_{\max }<0\right)\right.
$$

where $\left(\right.$ Ycap $_{\min }$ and $\left(Y_{\text {cap }}\right)_{\max }$ are the minimum and maximum values of GDP per capita respectively. The null hypothesis implies a U-shaped condition. If either of the two hypotheses is rejected, we can conclude that the regression has an inverted U-shaped condition. The inverted U-shaped conditions are shown in Equation (4), describing that when Ycap is still under the maximum value (Ycap still grew until reached the threshold), the curve will have an increasing trend. But then, the trend is likely to be reversed (decreased) after Ycap has reached a certain maximum value.

To verify the inverted-U shape of the Kuznets Curve, the signs and magnitudes of $\alpha$ and $\beta$ should be examined. The Kuznets Curve holds, if $\alpha>0$ and $\beta<0$. If it holds, then we can find the turning point or the maximum point of the Kuznets Curve using the following formula (Taguchi, 2012; Tam, 2008):

$$
k=\exp (-\alpha /(2 \beta))
$$

To test the determinant of inequality, we add control variables to Equation (2). The estimation using additional control variables was also applied in the studies of Nikoloski (2009) and Frazer (2006), and the specification of the model is: 


$$
\operatorname{Gini}_{i, t}=\gamma \operatorname{Gini}_{i .(t-1)}+\alpha \ln (\text { Ycap })_{i, t}+\beta \ln (\text { Ycap })_{i, t}^{2}+\delta Z_{i, t}+\mu_{i}+\varepsilon_{i, t}
$$

where $\operatorname{Gini}_{i, t}=$ income inequality (Gini ratio) in province $i$ at year $t$, Gini $i_{i(t-1)}=$ the one period lagged dependent variable, Ycap $=$ GDP per capita of province $i$ at year $t$, and $Z_{i, t}$ represents a vector of one or more control variables.

As the Kuznets theory mentioned, during the process of growth, there is a movement from low-productivity agricultural sector to more productive sectors, such as manufacturing and services. In order to control for the gradual shift towards industry and manufacturing, we use the share of agriculture sector and manufacturing sector to total GDP. We also use urban population as a control variable based on the hypothesis that the shifting from low productivity sector to more productive sectors, in the first place, will benefit the urban people. There has also been some research that has tapped into the relationship between inflation and inequality. Zhou (2009; as cited in Jiang, Shi, Zhang, \& Ji, 2011) found that inflation can significantly widen the income gap at the national level. In this paper, inflation is used in order to gauge the impact of macroeconomic volatility on inequality. Using inflation and real GDP per capita together in one model seemingly can raise the potential colinearity issue. But according to Baltagi (2005), this issue can be addressed by dynamic panel model. Jiang et al. (2011) and Son (2010) also used real GDP per capita together with inflation in one model to estimate relationship of that variable with inequality. Their paper presents the estimation result when one of real GDP either inflation dropped in order to check the impacts of a potential colinearity issue. Their estimation shows that there is only a slight difference if taking both real GDP and inflation into model or dropping one of them ${ }^{6}$. To accommodate the issue of human capital to inequality, we add variable Lschool. The complete specification of data and the expected sign is presented in Table 2.

Table 2

Data Specification

\begin{tabular}{|l|l|l|l|}
\hline Variable & Note & Source & Expected sign \\
\hline Gini & Gini ratio & BPS & $(+)$ \\
\hline Ycap & Real GDP per capita & BPS & $(+)$ \\
\hline Ycap ${ }^{2}$ & Real square of GDP per capita & BPS & $(-)$ \\
\hline CPI & Consumer Price Index with base year 2007 & BPS & $(+)$ \\
\hline Pop & Share of urban population over total population & BPS & $(+) /(-)$ \\
\hline S.Agriculture & Share of agricultural sector to total GDP & BPS & $(+)$ \\
\hline S.Industry & Share of manufacturing sector to total GDP & BPS & $(-)$ \\
\hline Lschool & $\begin{array}{l}\text { Number of students from elementary schools to higher } \\
\text { education universities }\end{array}$ & BPS & $(-)$ \\
\hline
\end{tabular}

Note. All data are converted to logarithm except for Gini and CPI.

In order to alleviate endogeneity and unobserved heterogeneity problem, this paper uses General Method of Moments System (GMM-SYS) which is a dynamic panel technique proposed by Arellano and Bover. This method uses instruments in first differences for equation in levels and instruments in levels for equations in first differences. The GMM-SYS technique estimates the dynamic panel model for both levels and first differences, as level equations are simultaneously estimated using differenced lagged regressor as instruments. This process, therefore, has the advantage of controlling for individual heterogeneity.

${ }^{6}$ That slight difference lends evidence to the effectiveness of the dynamic panel model in controlling colinearity bias (Baltagi, 2005). 
The unobserved heterogeneity problem can thus be effectively resolved by estimating first difference equations. The GMM method not only employs lag term $\left(\operatorname{Gini}_{i .(t-2)}\right)$ and difference $\left(\Delta \operatorname{Gini}_{i .(t-2)}\right)$ as instrument variables but also uses additional instruments obtained by utilizing the orthogonal conditions that exist between the disturbances and the lagged values of the dependent variable. This method makes a progress in utilizing instrumental variables in the dynamic panel analysis for lagged dependent model. Arellano and Bover found that computing the original level variable equation along with the difference equation as an instrument can improve the efficiency of the estimation (Son, 2010). Furthermore, the two-step GMM estimators, which use one-step residuals to construct asymptotically optimal weighting matrices, are more efficient than one-step estimators (Blundell \& Bond, 1998; as cited in Jiang et al., 2011).

The first-differenced endogenous variables of inequality $\left(\right.$ Gini $\left._{i, t}\right)$ with lagged of endogenous variable can be a valid instrument provided that there is no second-order autocorrelation in the idiosyncratic error terms using Arellano-Bond test. If there is an autocorrelation, it implies that the lagged variables, used as the instrumental variables, are in fact close to endogenous variables, not exogenous. Since the first degree of autocorrelation in the variable implies the second degree of autocorrelation in the error terms in difference equation $\left(\Delta \varepsilon_{i, t}=\varepsilon_{i, t}-\varepsilon_{i, t}\right)$, we can check the error term autocorrelation using the Sargan test.

This dynamic panel method testing the relationship between inequality and growth is found in Nikoloski (2009), Calderon and Chong (2001), Li and Zou (1998), Son (2010), as well as Grijalva (2011).

\section{Empirical Result}

Table 3 presents the dynamic panel GMM estimation results for testing whether the Kuznets Curve holds true for Indonesia (see Equation (2)). The two-step GMM-SYS method lends us a promising solution to the unobserved bias and endogeneity issue in estimating Equation (2). This method estimates both levels and first difference equations for Equation (2). The unobserved heterogeneity problem can thus be effectively resolved by estimating first difference equations, whereby the time-invariant disturbances are eliminated. Also, the extensive instrument variables (lag Gini ratio) utilized in this method can solve the endogeneity and even some other model specification problems.

To estimate the model in this paper, we conducted a two-step systematic GMM (GMM-SYS) that has met the criteria of the best model. In Verbeek (2004), the criteria for dynamic panel models with the best GMM approach are the validity of the instrument and the consistency. Based on the methodology of the GMM-SYS estimator, for each regression, we test the specification of equation with the Sargan test of over-identifying restrictions, and then with the Arellano-Bond test for the second-order serial correlation. The test results show that all the regressions satisfy the specification tests, which indicates that our instruments are valid and there exists no evidence of second-order serial correlation in our regressions.

As seen in Table 3, we find evidence of the existence of inverted U-shaped Kuznets Curve in Indonesia. In our model, GDP per capita and the squared term of the GDP per capita enter the equations with the expected sign (GDP per capita is positive, while the squared term is negative).

In terms of model robustness, the first criterion that we check is consistency. It can be seen from the results of the Arellano-Bond that the test is rejected at Order 1 using 10\% level of significance, because $p$-value $=0.0689$ and at Order 2 indicating that errors are serially uncorrelated, because $p=0.2060>0.05$. Thus statistically, it shows that the model is good enough. The second criterion is validity of the instrument, and the Sargan test shows that the insignificant $p$-value is 0.5904 , which means that the instrument is valid. 
Table 3

Dynamic Panel GMM-SYS Estimation of the Kuznets Curve Hypothesis

\begin{tabular}{llll}
\hline Gini ratio & Estimated coefficient & Standard error & $P>|z|$ \\
\hline L.Gini ratio & 0.7524 & 0.1303 & 0.000 \\
YCap & 0.0262 & 0.0107 & 0.014 \\
YCap & 2 & 0.0007 & 0.042 \\
Constant & -0.0013 & 0.0750 & 0.669 \\
\hline Arellano-Bond test & -0.0320 & Prob. $>z$ & \\
\hline Order 1 & $z$ & 0.0689 & \\
Order 2 & -1.8190 & 0.2060 & \\
\hline Sargan test & -1.2645 & \\
\hline Turning point & Chi2 $(11)=25.68395$ & \\
\hline
\end{tabular}

After verifying that inverted-U Kuznets Curve does hold in Indonesia, then the turning point of the Kuznets Curve can be examined. Table 3 shows the result that Indonesia may have the turning points when the real GDP per capita in each province reached 179.41 million rupiahs. From this evidence, we can conclude that with $7 \%$ growth each year and well-maintained macro-stability, it will take at least 25 years to reach the turning point.

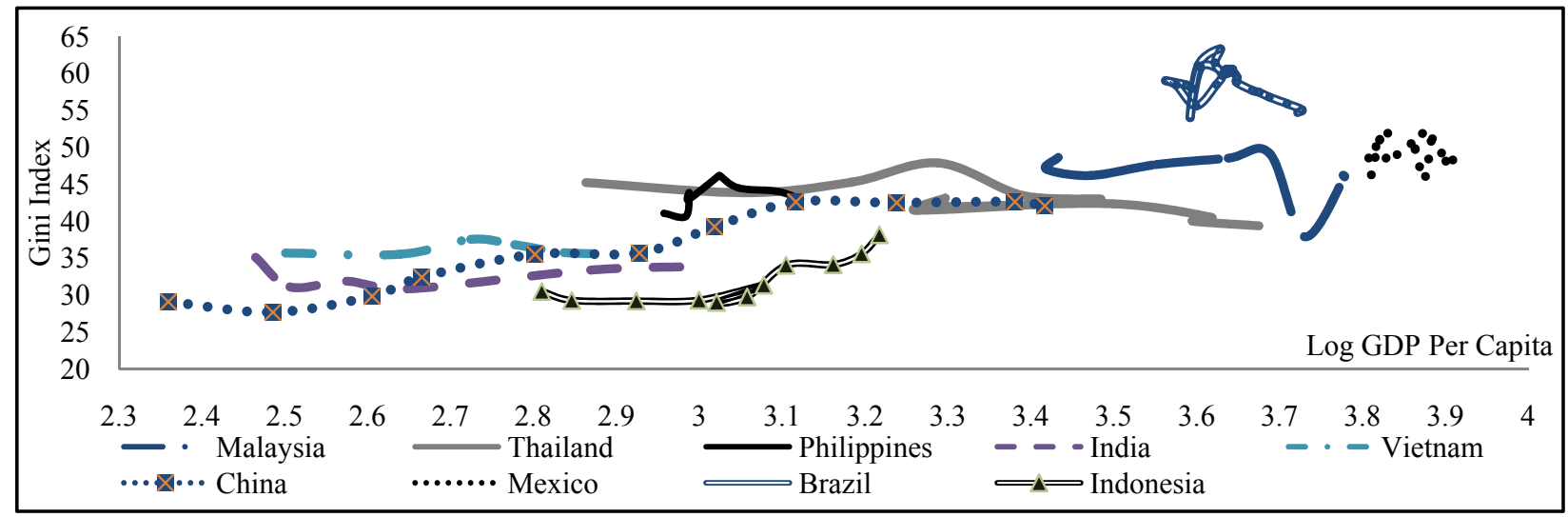

Figure 19. Kuznets Curve of some countries.

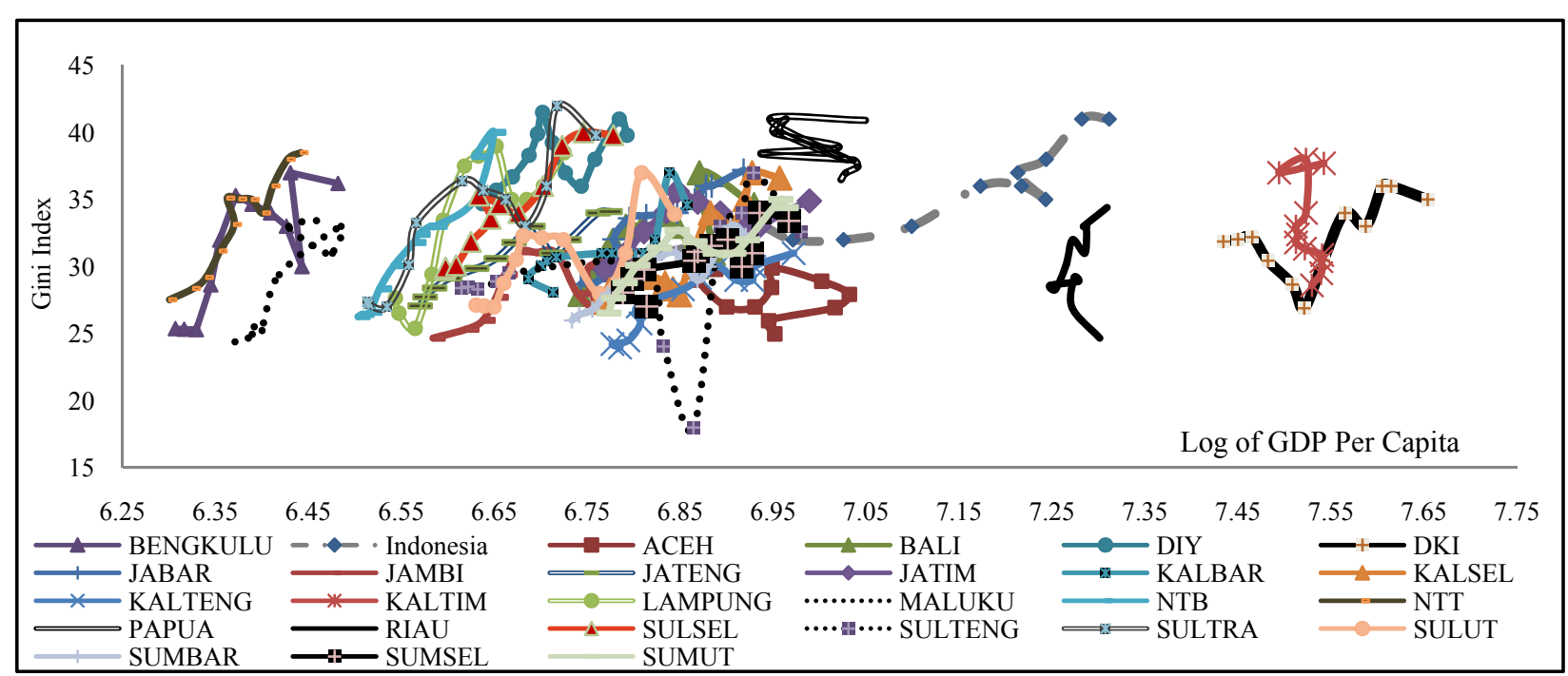

Figure 20. Kuznets Curve of Indonesian provinces. 
Figure 19 shows a plot of Kuznets Curve in some countries using log GDP per capita and Gini index. Indonesia and India seem still in the first stage of development according to Kuznets hypothesis where increase in GDP per capita is accompanied by increase in inequality. Meanwhile, the plot for Brazil and Mexico seems not linear and more complex. In empirical fact, after the burst of economic growth in the middle of the last century and after reaching middle-income group for 40-50 years ${ }^{7}$ (income group classification by World Bank $^{8}$ ), Brazil and Mexico experienced something like a middle-income trap and have yet to progress to advanced economic status. For Malaysia, the plot appears to be an inverted-S curve. If seen from the current facts found, Malaysia has reached the middle-income category since 40 years ago, but Malaysia has not yet fallen into the middle-income trap categories.

When we see closer to the level of province in Indonesia, it can be seen from Figure 20 that almost all provinces in Indonesia are experiencing the rising inequality which is in line with the national movement. For provinces with higher GDP per capita than provincial average such as Jakarta, Riau, and East Kalimantan, it is clear that increasing GDP per capita is in line with the increase of income inequality.

The result for estimation of determinant of inequality is presented in Table 4. All the independent variables are significant with signs as expected. The coefficients of lag Gini ratio are positive and significant at the level of $1 \%$ for regression which suggests a strong support for dynamic effect of inequality in the model. Indeed, higher past levels of inequality are associated with higher current levels of inequality. Lagged levels of Gini ratio are positively significant at the level of $1 \%$, which shows a strong positive correlation between past and present values of Gini ratio. We also find evidence of the existence of the inverted U-shaped Kuznets Curve after adding some control variables. The coefficients GDP per capita and the squared term of the GDP per capita showed signs of the inverted-U shape and are significantly different from zero. The model also met the robustness criteria of consistency and validity of instruments.

Table 4

Dynamic Panel GMM-SYS Estimation of Kuznets Curve Hypothesis

\begin{tabular}{llll}
\hline Gini ratio & Estimated coefficient & Standard error & $P>|z|$ \\
\hline L.Gini Ratio & 0.1850 & 0.0179 & 0.000 \\
YCap & 0.1566 & 0.0298 & 0.000 \\
YCap & -0.0015 & 0.0000 & 0.000 \\
Pop & 0.0696 & 0.0340 & 0.041 \\
CPI & 0.0005 & 0.0000 & 0.000 \\
Schooling & -0.0604 & 0.0100 & 0.000 \\
S.Agriculture & 0.0415 & 0.0167 & 0.013 \\
S.Industry & -0.0343 & 0.0049 & 0.000 \\
\hline Arellano-Bond test & $z$ & Prob. $>z$ & \\
\hline Order 1 & -1.9176 & 0.0552 & \\
Order 2 & -1.4867 & 0.1371 & \\
\hline Sargan test & Chi2 $(11)=24.83771$ & & \\
\hline
\end{tabular}

\footnotetext{
7 This fact is mentioned in Economic Insight (Maccalum \& Moretti, 2013).

${ }^{8}$ World Bank divided countries into four income group categories based on income per capita. The groups are: low-income countries with income per capita $\$ 1,035$ or less; lower-middle-income $\$ 1,036-\$ 4,085$; upper-middle-income $\$ 4,086-\$ 12,615$; and high-income countries with income per capita $\$ 12,616$ or more.
} 
We find strong evidence that the percentage of urban population is associated with the higher level of inequality. This happens because in the early stages of development, economic development comes with increasing urbanization and inequality. Increasing returns of industrial activities, decreasing transport costs, and labor mobility generate the concentration of workers and economic activity in the urban sector, allowing higher urban wages. As people and resources are reallocated from agricultural activities towards industrial activities, this process leads to increasing inequality, as higher incomes are perceived in urban areas compared to rural areas. Both higher inequality and higher urbanization favor the concentration of production factors necessary for growth, and this concentration itself reinforces labor's reallocation from the rural towards the urban areas (Ros, 2000; Castells \& Royuela, 2011). This finding is similar with Kanbur and Zhuang (2013) whose empirical evidence shows that higher urban population in the early stages of development in Indonesia will raise inequality. The paper also shows that Indonesia has not reached the turning point yet. For Indonesia, the current composition of urban population is around $47 \%$, which is still far lower than the predicted turning point of $84.9 \%$. That finding shows that Indonesia still has many years to go for national inequality to peak even if urban and rural inequalities and the urban-rural income gap stay constant. From this empirical evidence, it is useful to know that shifting population from the rural to urban sectors, holding all other factors constant, will increase national inequality for Indonesia in the early stages of development.

We also find that higher inflation is associated with higher inequality. Inflation can increase inequalities through its effect on individual income and can reduce inequalities in the presence of progressive tax system. The inequality widening effect of inflation is more pronounced when wages fail to chase increasing price levels. In developing countries, trade unions are weak and minimum wage laws are dysfunctional in the presence of weak institutions. Thus, workers are left with less or no rise in wages, while owners of the firms enjoy benefits of rising prices and get richer (MacDonald \& Majeed, 2010).

From the empirical result, this paper also finds that education has a negative impact on income inequality. This result convinces the theory that education is widely seen as one of the most efficient ways to reduce inequality (Abdullah, Doucouliagos, \& Manning, 2011; Meschi \& Scervini, 2012). Education provides greater economic opportunities especially to the poor, because it determines occupational choice and the level of pay and it also provides a signal of ability and productivity in the job market. Education shifts the composition of the labour force away from unskilled to skilled. Better educated individuals are perceived to be more able to cope with technological tools that directly influence productivity levels, which are needed by Indonesia as a low middle-income country to move to a higher level economy.

As Kuznets theory mentioned, during the process of growth, there is a movement from low productivity agriculture to more productive sectors, such as manufacturing and services. We find some support for Kuznets' original suggestion that changes in the structure of production provide a mechanism through which development affects inequality. The share of agriculture in total GDP is significantly related to the pattern of inequality. Higher share of agriculture in total GDP is associated with higher inequality. As the modern sector expands, it absorbs larger proportions of the labor force into high income employment, thus reducing the pressure of population in the traditional sectors and thereby narrowing inter-sector income differentials. The empirical result of this paper also finds that the share of industrial sector over total GDP has a negative significant effect on income inequality. This result shows that a rising share of the modern sector (mainly the manufacturing industry) in terms of GDP makes income distribution unequal in the early stages of economic 
development. As Kuznets theory mentioned before, the process of development is supposed to be accompanied by a rise in the shares of the non-agricultural sectors and a corresponding fall in the share of the agricultural sector in total output.

\section{Conclusion}

Poverty has been decreased while inequality has been increased both by national aggregate and provincial data. The increase in GDP per capita has succeeded in reducing the number of poor people, but inequality is keeping rising.

The increase in inequality for the last five years is higher compared to that in the period of two decades before. Higher inequalities mostly occurred in urbanized provinces or in provinces with high GDP per capita. Almost all provinces experience an increasing trend of inequality.

This study indicates that the Kuznets Curve holds in Indonesia. It seems that the current increasing trend of inequality is expected to continue.

Percentage of urban population, inflation, and share of agricultural sector contributed to the increase of inequality, while high-level education and share of industrial sector are associated with the lower level of inequality.

\section{References}

Abdullah, A. J., Doucouliagos, H., \& Manning, E. (2011). Education and income inequality: A meta-regression analysis (University Teknologi Mara, Sarawak, Malaysia).

Arcand, J. L., Berkes, E., \& Panizza, U. (2012). Too much finance? IMF Working Paper No. WP/12/161.

Baltagi, B. H. (2005). Econometric analysis of panel data (4th ed.). Chichester: John Wiley \& Sons.

Barro, R. J. (2008). Inequality and growth revisited. ADB Working Paper on Regional Economic Integration No. 11.

Boston Consulting Group. (2012). Asia's next big opportunity: Indonesia's rising middle-class and affluent consumer report.

Calderon, C., \& Chong, A. (2001). External sector and income inequality in interdependent economies using a dynamic panel data approach. Economics Letters, 71(2), 225-231.

Castells, D., \& Royuela, V. (2011). Agglomeration, inequality, and economic growth. Research Institute of Applied Economics.

Frazer, G. (2006). Inequality and development across and within countries. World Development, 34(9), 1459-1481.

Grijalva, D. F. (2011). Inequality and economic growth: Bridging the short-run and the long-run. University of California, Irvine.

Jiang, Y., Shi, X., Zhang, S., \& Ji, J. (2011). The threshold effect of high-level human capital investment on China's urban-rural income gap. China Agricultural Economic Review, 3(3), 297-320.

Kanbur, R., \& Zhuang, J. (2013). Urbanization and inequality in Asia. Asian Development Review, 30(1), 131-147.

Lessmann, C. (2011). Spatial inequality and development-Is there an inverted-U relationship? CESifo Working Paper No. 3622.

Lewis, D. B. (2013). Urbanization and economic growth in Indonesia: Good news, bad news, and (possible) local government mitigation. Regional Studies, 48(1), 192-207.

Li, H., \& Zou, H. F. (1998). Income inequality is not harmful for growth: Theory and evidence. Review of Development Economics, 2(3), 318-334.

Lind, J. T., \& Mehlum, H. (2010). With or without U? The appropriate test for a U-shaped relationship. Oxford Bulletin of Economics and Statistics, 72(1), 109-118.

Maccalum, J., \& Moretti, G. (2013). Economic insight. Middle Kingdoms UBS.

MacDonald, R., \& Majeed, M. T. (2010). Distributional and poverty consequences of globalization: A dynamic comparative analysis for developing countries. University of Glasgow.

Meschi, E., \& Scervini, F. (2012). Expansion of schooling and educational inequality in Europe: Educational Kuznets curve revisited. Gini Discussion Paper 61.

Miranti, R., Vidyattama, Y., Hansnata, E., Cassells, R., \& Duncan, A. (2013). Trends in poverty and inequality in decentralising Indonesia. OECD Social, Employment, and Migration Working Paper.

Nikoloski, Z. (2009). Economic and political determinants of income inequality. University of College London. 
Ranjan, P. (2001). Dynamic evolution of income distribution and credit-constrained human capital investment in open economies. Journal of International Economics, 55(2), 329-358.

Ros, J. (2000). Development theory and the economics of growth. Ann Arbor: University of Michigan Press.

Son, J. C. (2010). A reassessment the relationship between growth and inequality: Evidence from new data. Institute for Monetary and Economic Research, the Bank of Korea.

Stern, D. I. (2004). The rise and fall of the environmental Kuznets curve. World Development, 32(8), 1419-1439.

Taguchi, H. (2012). The environmental Kuznets curve in Asia: The case of sulphur and carbon emissions. Asia-Pacific Development Journal, 19(2), 77-92.

Tam, H. (2008). An economic or political Kuznets curve? Public Choice, 134(3/4), 367-389.

Verbeek, M. (2004). A guide to modern econometrics (2nd ed.). Chichester: John Wiley \& Sons. 